\title{
RUSSKAYA PRAVDA: PECULIARITIES OF TEXT PERCEPTION IN THE WEST
}

\author{
Vera A. Mityagina \\ Volgograd State University, Volgograd, Russian Federation \\ Svetlana A. Korolkova \\ Volgograd State University, Volgograd, Russian Federation \\ Evgeniya A. Shovgenina \\ Volgograd State University, Volgograd, Russian Federation \\ Aleksandr N. Shovgenin \\ Volgograd State University, Volgograd, Russian Federation
}

\begin{abstract}
The article deals with a review of studies of the most famous and important papers of European and American researchers devoted to Russkaya Pravda (also translated into English as "Russian Justice" or "Russian Truth"), i.e. monumental legal text of Ancient Russia.

The authors represent the opinions of German, British, American and French scholars, historians and lawyers in the first place, whose studies involve primarily a comparative text analysis of the Russkaya Pravda with the law systems in other countries of that period (Germanic, Swedish, Anglo-Saxon and Frankish law).

The article shows that the researchers analyze the influence of foreign legal traditions on the Russkaya Pravda (e.g. Scandinavian influence from the point of view of political relations).

It demonstrates some scholars attempt to determine what Russkaya Pravda is: "local customary law" or the ¿ embodiment of "princely law".

A number of studies offer evidence of the evolution of justice in Russia by comparing the text of the "Russian Truth" with the later monuments of the legislative discourse, which reflect a shift towards greater social justice. The few philological works carry out terminological analysis based on the interpretation of the translation: the groups of lexical elements are identified, which are most difficult for adequate translation, since they reflect the realities of life in the medieval period in the Russian history; the ways to interpret this vocabulary are suggested. difficulties.

\section{«РУССКАЯ ПРАВДА»: ОСОБЕННОСТИ ВОСПРИЯТИЯ В ЕВРОПЕЙСКОМ И АМЕРИКАНСКОМ НАУЧНОМ ПРОСТРАНСТВЕ}

\author{
Вера Александровна Митягина
}

Волгоградский государственный университет, г. Волгоград, Российская Федерация

\section{Светлана Азадовна Королькова}

Волгоградский государственный университет, г. Волгоград, Российская Федерация

\section{Евгения Александровна Шовгенина}

Волгоградский государственный университет, г. Волгоград, Российская Федерация 


\title{
Александр Николаевич Шовгенин
}

Волгоградский государственный университет, г. Волгоград, Российская Федерация

\begin{abstract}
Аннотация. В статье предложен краткий обзор наиболее известных и актуальных работ европейских и американских исследователей, посвященных такому монументальному правовому тексту Древней Руси, как «Русская Правда». Представлены труды немецких, британских, американских и французских ученых, прежде всего историков и юристов, в которых проводится сопоставительный анализ текста «Русской Правды» с законоуложением других стран того времени (германским, шведским, англосаксонским и франконским правом). Показано, как зарубежные специалисты анализируют влияние на «Русскую Правду» зарубежных правовых традиций (скандинавское воздействие с точки зрения политических отношений). Некоторые авторы предпринимают попытку определить, чем является «Русская Правда»: «местным обычным правом» или воплощением «княжеского права». В ряде работ предложены доказательства эволюции правосудия на Руси путем сравнения текста «Русской Правды» с более поздними памятниками законодательного дискурса, которые отражают переход к большей социальной справедливости. В немногих филологических работах проводится терминологический анализ, основанный на интерпретации сложностей перевода: выявляются группы лексем, наиболее сложных для адекватного перевода, отражающих реалии жизни средневековых русичей; предлагаются пути интерпретации такой лексики.
\end{abstract}

Ключевые слова: «Русская Правда», сопоставительный анализ, законодательный дискурс, комментированный перевод, сложности перевода.

1

«Русская Правда» как культурное достояние представляет собой важнейший документ, отражающий общий исторический фон средневековой Руси, о ней написаны десятки книг и сотни статей. Однако, по справедливому замечанию О.И. Усенко, в настоящий момент при исследовании «Русской Правды» «есть потребность критически осмыслить опыт предшественников и творчески использовать наработки отечественных и заграничных ученых в самых разных областях гуманитарных наук» [Усенко, 2007, с. 81].

\section{2}

«Русская Правда» неоднократно находилась в фокусе внимания западных исследователей. История открытия и научного осмысления «Русской Правды» изначально являет собой одно из центральных направлений российско-германского сотрудничества: найденная В. Татищевым, она впервые была опубликована в 1767 г. Августом Людвигом Шлецером (August Ludwig Schlözer) - помощником Герхарда Фридриха Миллера (Gerhard Friedrich Müller) - в издании «Собрания российских историй».

А.Л. Шлецер принес в российскую историческую науку уже освоенные на Западе приемы критики исторических источников, он придавал большое значение пропаганде российской истории в Европе, оставаясь сторонником норманнской теории, называл себя русским патриотом (подробнее см.: [Данилов, 1998; Орлов и др., 2012]).

Оппонентом Шлецера являлся в первую очередь Иоганн Филипп Густав Эверс (Johann Philipp Gustav von Ewers). В 1826 г. Эверс издает «Древнейшее право руссов в его историческом развитии» [Ewers, 1826]. В этой монографии он рассматривает русско-византийские договоры, «Русскую Правду» и другие юридические акты, исходя из собственных методологических принципов: во-первых, все события объясняются внутренним развитием общества, через призму родовых отношений; во-вторых, действие любого исторического лица воспринимается как отражение определенных общественных условий; в-третьих, древнейшее право россов рассматривается на основании понятий и отношений, свойственных древним народам, а не на основе правил настоящего времени, поэтому законодательный акт и право в целом исследуются им в соотнесении с определенным уровнем развития общества, с политическим и внешнеполитическим контекстом. Исходя из этого, и критика источника осуществляется на совершенно новом текстологическом уровне.

В «Русской Правде» им выделены три части (Правда Ярослава - с 1 по 18 статью, Правда Ярославичей - с 19 по 35 статью, 
«Русская Правда»: особенности восприятия в европейском и американском научном пространстве

Правда XIII столетия - Пространная). На основе ее текста он проследил эволюцию правовых отношений (например, право кровной мести) в переходный период от родового быта в быт государственный. (Подробно рассматривает деятельность И.Ф.Г. Эверса нижегородский историк М.В. Зеленов в электронном проекте «Открытый текст» (см.: [Зеленов]).)

Идеи А. Шлецера и И. Эверса были синтезированы в исследованиях Леопольда Карла Гетца (Leopold Karl Goetz). Примечательно, что именно он стал одним из первых, кто изучал «Русскую Правду» за пределами России. Его труды о «Русской Правде» - это классический вариант по-немецки скрупулезного, «инвентаризационного» дескриптивного анализа. В 1909 г. им был опубликован комментированный перевод текста, а год спустя - первый том многотомного издания, содержащий первую редакцию «Русской Правды» [Goetz, 1909, 1910]. Сегодня оценка деятельности Л.К. Гетца - это констатация того, что в его исследованиях акцент сделан на восточно-европейской истории и славистике, который обусловлен не в последнюю очередь влиянием глубокого погружения в изучение эволюции текста «Русской Правды».

Очевидно, что труды немецких историков XVIII - начала XX в., основательные, подробные, уважительные к историческому документу, определили основные тенденции дальнейшего исследования «Русской Правды». Приведем два примера (результаты случайной выборки) «среднестатистической» оценки этого документа современными немецкоязычными исследователями.

Дитер Штраух (Dieter Strauch), профессор права Кельнского университета, в объемном дополнительном 73-м томе «Энциклопедического справочника по германской древней истории» под названием «Средневековое скандинавское право до 1500 г.: источники» (перевод здесь и далее наш. - B. M., C. K., $E$. $Ш ., A . Ш$.) сравнивает российское и скандинавское право и отмечает существенное влияние скандинавского права в первую очередь на «Русскую Правду» (подробнее см.: [Strauch, 2011]).

Доктор Урсула Бибер (Ursula Bieber), научный сотрудник Зальцбургского университета, руководитель Российского центра, специ- алист по медиевистике, славист, в курсе лекций Междисциплинарного центра исследований Средневековья «Криминальное Средневековье», прочитанном в 2004/05 учебном году, предложила лекцию на тему «Преступление и дьяволиада в русских хрониках», в которой:

- «Русская Правда» характеризуется как самый древний и влиятельный памятник древнерусского права;

- проводится семантический и этимологический анализ слова правда;

- предпринимается текстологический анализ документа, изложена эволюция документа, его разных редакций и представлена история публикации «Русской Правды» Августом Шлецером;

- отмечается, что «Русская Правда» содержит нормы наказания древнего восточнославянского традиционного права (прежде всего, кровную месть);

- подчеркивается значимость «Русской Правды» в истории права России;

- определяется статус документа как культурного и образовательного достояния;

- отмечается роль исследования «Русской Правды» для осмысления «пути Киевской Руси от неопределенности привычки к определенности права, от мести к соразмерному штрафу, от спасения собственными силами к защите жизни и здоровья, собственности и владения»;

- характеризуются изменения, которые происходили с текстом «Русской Правды», они названы «постепенными и осторожными» (подробнее см.: [Bieber]).

Таким образом, можно говорить о том, что с точки зрения восприятия текста немецкими исследователями «Русская Правда» выступает инициальным феноменом формирования объективной характеристики истории права на Руси, историческим документом, свидетельствующим об устойчивых традициях развития России как правового государства.

В литературе на английском языке встречаются следующие транслитерированные соответствия: Rus'ka Pravda или Ruska Pravda (что соотносится с употреблением современного украинского языка), а также Russkaia 
Pravda или Russkaya Pravda (что соотносится с употреблением современного русского языка). Термин Русская Правда обычно переводят на английский язык как Justice of the $R u s$, по-видимому, под влиянием латинского ius russicum. Часто встречается и соответствие Russian Truth, основанное на современном значении слова правда.

В Оксфордский словарь Средневековья под редакцией Роберта Э. Бьорка (The Oxford Dictionary of the Middle Ages), опубликованный он-лайн в 2010 г., включена словарная статья, посвященная «Русской Правде». В ней дается отсылка к старославянскому языку [Old Slavic: (Старославянский): Правда Русьская] и приводится буквальный перевод названия на английский язык: Russian Truth («Русская Правда»). «Русская Правда» определяется как «первый правовой кодекс восточных славян». Отмечается существование трех редакций: Краткой, Пространной и Сокращенной, причем на английском языке дается транслитерация этих слов (Kratkaya, Prostrannaya, Sokraschennaya). При этом Краткая редакция называется старейшей, сообщается, что уцелело только два списка; данная редакция содержит две основные части. Более ранняя, так называемая Древнейшая (Drevneyshaya), принята Ярославом Мудрым в Новгороде в 1015/16 году. Подчеркивается, что данный документ «представлял собой первое регулирование уголовного права, сдерживающее устаревшие обычаи, например, такие как кровная месть» (подробнее см.: [The Oxford Dictionary, 2010]). Вторая часть, отредактированная от имени сыновей Ярослава (датируемая по-разному: от первой половины ХІ в. до 1136 г.), была посвящена, главным образом, княжеской наследственной собственности, в ней была отменена кровная месть.

Пространная редакция (сохранившаяся в более чем ста списках) может датироваться началом XII века (или, по мнению некоторых ученых, значительно более поздним периодом). Согласно словарной статье, в «Русской Правде» отражается более сложное общество, разделенное на разные социальные слои, высшие (например, князья и их приближенные) и нижние (например, холопы и закупы), затрагивается вопрос существования состояния личной подневольности. Соответ- ственно, штрафы (виры), выплачиваемые князю за преступления, зависели от социального положения потерпевшего. Большое внимание уделено судебным процедурам, например, таким как сбор улик, опрос свидетелей, принесение присяги и т. д. В статье указано, что сокращенный вариант был составлен гораздо позже, в послемонгольский период [The Oxford Dictionary, 2010].

Далее следует отметить работу Г.В. Вернадского, представлявшую собой перевод «Русской Правды» на английский язык [Vernadski, 1947]; именно на нее многочисленные зарубежные авторы ссылались в своих трудах, посвященных этому монументальному законодательному памятнику. Г.В. Вернадский не только перевел письменный памятник российской истории права на английский язык, но и сопроводил его издание обширными комментариями.

Научный труд Г.В. Вернадского отмечен в опубликованной в 1969 г. книге Томаса Рихи (Thomas Riha). Ученый пишет, что работа профессора Вернадского, которая используется в его книге «остается самым тщательным исследованием российского права в период перед становлением Великого Московского княжества» [Riha, 1969]. Имеет место и характеристика непосредственно самого документа. Сначала Т. Риха констатирует, что первый российский свод законов был собран воедино в период правления Ярослава Мудрого и стал известен под такими названиями, как «Российское право» (в тексте на английском языке приводятся следующие аналоги: The Russian Law or Lex Russica), а также «Правда Ярослава»; базируясь на обычном праве, он содержит главным образом нормы уголовного права.

Далее Т. Риха, ссылаясь на другого англоязычного автора, утверждает, что существует поразительное сходство между некоторыми статьями «Русской Правды» и положениями законов короля Альфреда Уэссекского: «Любой англичанин, как писал британский ученый Б.Г. Саммер, (В.Н. Summer), который читает "Русскую Правду", ощущает себя так, будто он находится в мире королей Уэссекса», при этом отмечая, что сходство средневекового российского права с западным законоуложением можно было бы, без сомнения, 
«Русская Правда»: особенности восприятия в европейском и американском научном пространстве

объяснить, но до сих пор это не было предпринято в полной мере.

«Русская Правда» характеризуется им как документ, представляющий собой важнейший материал, иллюстрирующий общий исторический фон средневековой Руси.

Не менее интересна работа американского историка права Д.Х. Кайзера (Daniel H. Kaiser) [Kaiser, 1980]). Он является переводчиком и редактором текстов, его переводы опубликованы наряду с другими правовыми текстами в книге «Законы Руси: десятый - пятнадцатый века» [Kaiser, 1992]. При этом на его труд ссылаются как на «историю раннего опыта изучения «Русской Правды». Д.Х. Кайзер отмечает, что «Русская Правда» была описана попеременно в качестве русского княжеского права или совокупности местного обычного права. Мало сомнений в том, что данный свод законов был создан по приказу или с одобрения князей времен ранней Руси и служил для того, чтобы защитить в первую очередь их интересы. Хотя самые ранние физические копии любой версии «Русской Правды» датируются только концом тринадцатого века, Д.Х. Кайзер считает, что «нет правдоподобных причин сомневаться, что “Краткая Правда" была записана в одиннадцатом столетии» (цит. по: [Толочко, 2009]).

В своем развитии «Русская Правда» подчиняется интуитивно ожидаемой закономерности - она «нарастает» от более кратких к более пространным редакциям. Достаточно удачно это сформулировал Саймон Франклин (Simon Franklin) [Franklin, 2002], указавший на то, что следующие друг за другом редакции «Правды» демонстрируют в течение XI и XII вв. расширение сферы общественных деяний, связанных с княжеским письменным законодательством. «Краткая Правда», начинающаяся с общих положений об уголовных преступлениях, личном оскорблении и кражах, переходит к единичным расценкам штрафов в отдельных случаях: штрафов за убийство княжеского конюха, тиуна, смерда или холопа; штрафов за кражу ладьи, голубя, пса, козы, сена. Пространная «Правда» частично уточняет наказания за аналогичные проступки (подразделяя, например, различные виды увечий, полученных в драке), но также вводит дополнительные наказания за имущественные и общественные проступки. Таким образом, разрастаясь, постановления расширяют социальную и экономическую сферу своего применения.

В 1997 г. частным американским университетом Брендайс была издана книга «Russia. A History», посвященная истории России и написанная тринадцатью авторами под редакцией профессора Г.Л. Фриза (Gregory L. Freeze). В первой главе описывается политико-экономическая ситуация во времена княжения Владимира и Ярослава и констатируется, что после того, как сын Владимира великий князь Ярослав (ум. 1054) издал кодекс законов, известный как «Русская Правда», на Руси князья стали ярыми сторонникам закона Рюриковичей. Отправление правосудия, которое поддержало как власть Рюриковичей, так и социальный порядок, принесло доходы в виде судебных пошлин и штрафов. «Русская Правда», дополненная сыновьями Ярослава, и более поздние положения, которые вносились в документ вплоть до XIII в., оставались в силе долгое время после Киевской эпохи, пока в 1497 г. не был принят новый свод законов (Судебник) (см.: [Martin, 1997]).

Таким образом, в среде англоязычных исследователей представлены различные мнения об истоках «Русской Правды», но все ученые сходятся во мнении, что она стала отправной точкой формирования принципиально нового этапа в истории российской государственности.

4

Восемнадцатый век стал веком открытия России для европейских государств: интерес к истории Российской империи возникает в среде французских мыслителей и исследователей. Наиболее ярким представителем этой эпохи был Пьер-Шарль Левек (PierreCharles Lévesque), который в 1804 г. сделал во французской Академии надписей и изящных искусств доклад «Записки о кодексе законов, данном жителям Новгорода великим князем Ярославом, и кодексе великого князя Владимира Мономаха» [Lévesque]. К сожалению, этот труд так и не был издан даже в сокращении и поэтому до 1962 г. не был известен ни специалистам, ни широкой публике. 
Однако это была первая работа иностранного исследователя, полностью посвященная «Русской Правде». В 1962 г. во французском научном журнале «Revue des études slaves» был опубликован труд П.-Ш. Левека, обнаруженный и подготовленный к публикации двумя другими крупнейшими специалистами в области русской истории и филологии Андре Мазоном (André Mazon) и Мишелем Лараном (Michel Laran). Предваряла публикацию статья выдающегося отечественного исследователя С.Н. Валка [Valk]. К 1000-летию «Русской Правды» была опубликована статья В.В. Андреева «Пьер-Шарль Левек о Русской Правде Ярослава Мудрого», в которой автор знакомит российскую научную общественность с данным сочинением [Андреев, 2015].

Труд Левека и на нынешнем этапе развития историографической науки значим не только как исторический документ, поскольку позволяет проследить извилистый путь развития русской историографии на Западе [Андреeв, 2012; Lévesque и др.]. Итак, «Записки...» Левека представляют собой постатейный перевод «Русской Правды» на французский язык с комментариями и историческими сравнениями с афинскими и салическими законами. Однако при переводе Левеком были допущены некоторые ошибки, обусловленные, по мнению А. Мазона и М. Ларана, тем, что он работал с текстом И.Н. Болтина, в котором содержались неправильные толкования и неточности перевода на современный русский язык древнерусского текста [Lévesque]. Левек ставил задачу через законы, оформленные в кодекс Ярославом, понять, как жило общество в Древней Руси, как оно было организовано и структурировано, каковы были обычаи, нравы и традиции русичей той эпохи. Так, автор отмечает, что «Русская Правда» позволяет понять, что торговцы и ремесленники играли важную роль в обществе, что князь оказывал всяческую поддержку и покровительство иноземным купцам. Именно это значительно отличает общество франков от русичей: в законах франков «нет никакого упоминания о ремесленниках, а купцы очень долго подвергались грабежу, поборам со стороны аристократов из замков вместо защиты» [Lévesque, p. 32]. По утверждению автора, «"Русская Правда" гарантирует защиту тор- говле и, исходя из полезности иностранцев торговле, защиту иностранцам», а жители «всячески завлекали иностранцев в свой город, поскольку они приносили с собой свои капиталы, свои связи и свое производство» [Lévesque, c. 35].

Левек соглашается с мнением И.Н. Болтина о том, что кодекс Ярослава Мудрого не является первым сводом законов русичей и отсылает к договору Олега и греков, где уже изложены законы, регулирующие их взаимоотношения. Левек полагает, что большая часть законов существовала уже задолго до правления князя Олега, а заслуга Ярослава Мудрого заключается в том, что он впервые собрал, записал их и дополнил новыми законами, продиктованными возникновением новых взаимоотношений и обычаев. Левек подкрепляет эту мысль сопоставлением «Русской Правды» с салическими законами франкских королей, которые переписывались и дописывались многократно. При этом он придерживается общего мнения, что Ярослав - это первый законодатель Руси [Lévesque, p. 32-33].

Интересен тот факт, что в своей работе Левек уделил большое внимание положению женщины в древнерусском обществе. Так, он отдельно рассмотрел статью, регулирующую процесс наследования. Автор выделил следующие положения: мать могла завещать свое имущество тому из сыновей, который проявлял наибольшую почтительность и уважение по отношению к ней; она могла полностью лишить своих сыновей наследства в пользу дочери. По его мнению, эти положения «очень трогательны, поскольку обеспечивали матерям счастливую старость и добросовестный уход, по крайней мере со стороны хотя бы одного ребенка» [Lévesque, p. 58].

Другой гендерный момент, вызвавший восхищение автора, - это статья о штрафе за убийство раба (за убийство раба-мужчины следовало выплатить 5 гривен, за убийство рабыни штраф составлял 6 гривен); она сопровождается следующим комментарием Левека: «...при суровости нравов того времени остается только удивляться такому отношению законодателя к слабому полу» [Lévesque, p. 41-42].

В целом Левек достаточно корректно рассмотрел русское законодательство того 
времени, выделив значимые для общества традиции и обычаи и сумев их интерпретировать с уважением и пониманием, указав, что «многие положения кодекса русских вызывают восхищение своим гуманизмом, другие кажутся странными и нелепыми. Однако в этом виноваты не законодатели, а эпоха». При этом следует отметить еще один важный момент: Левек считал, что наличие «Русской Правды» свидетельствует о достаточно высоком уровне цивилизационного развития древнерусского общества: «народ, способный создать кодекс законов, давно преодолел большое количество цивилизационных ступеней, и он уже достаточно далек от дикого состояния» [Lévesque, p. 32].

В течение XIX в. французские исследователи не раз обращались к изучению «Русской Правды», к сожалению, вне контекста работы П.-Ш. Левека. Так, в первую очередь следует процитировать работу Иогана-Генриха Шнитцлера (Jean-Henri Schnitzler), опубликованную в Париже и Санкт-Петербурге в 1829 г., и труд Родольфа Дареста (RodolpheMadeleine Cléophas Dareste de la Chavanne), изданный в 1889 г. в Париже.

В труде И.-Г. Шнитцлера «Русская Правда» упоминается автором в IV разделе «Justice et législation» («Правосудие и законодательство») седьмой главы «De la constitution politique et de l'administration» («О политическом устройстве и администрации»). Анализ кодекса Ярослава у данного автора выполнен в русле царивших тогда исторических взглядов. Он полагает, что это первый письменный правовой документ, отражающий «детский» этап развития общества [Schnitzler, p. 273], что многие положения позаимствованы у скандинавских и германских племен, что гражданское право и уголовное право не разделены и отсутствует указание на появление понятия «наказание», поскольку законы не карают, а возмещают потерю или причиненное истцу зло [Schnitzler, p. 274-275]. При этом стоит отметить, что И.-Г. Шнитцлер полагал, что хотя в современной ему России не существует письменных кодексов законов, а правосудие «в основном воплощено в личности императора, а каждый издаваемый им указ имеет силу закона» [Schnitzler, p. 270], тем не менее именно «Русская Правда», свод законов Ярослава
Мудрого, многократно дополненный и измененный, уже не отвечающий по многим позициям современной ситуации, остается основой русского законодательства, основой судебных решений [Schnitzler, p. 271].

Работа Родольфа Дареста (Rodolf Dareste) посвящена обзору истории права от Египта до салических законов германских племен. В IX главе этого серьезного труда «L'ancien droit slave. Les Russes» («Древнее право славян. Русские») анализируется «Русская Правда», кодекс Ярослава. Р. Дарест придерживается мнения, что «Русская Правда» представляет собой несколько документов: первоначальный, датируемый 1019 г., данный князем Ярославом новгородцам, второй 1054 г., дополненный сыновьями Ярослава Изяславом, Святославом и Всеволодом, и, наконец, последний, созданный между 1280-1299 гг., с многочисленными комментариями и пояснениями из реальной судебной практики. Отметим, что автор, придерживаясь в основном общепринятого взгляда на документ, тем не менее вступает в полемику по некоторым историческим аспектам. Например, он не согласен с тем, что «Русская Правда» отражает сильное влияние, оказанное германскими племенами на русичей через скандинавских варягов. Дарест считает, что «это утверждение не имеет никакого обоснования: русичи были в состоянии изобрести свою виру, так же как и германские племена придумали свой “wergeld". К тому же скандинавы не были германскими племенами, и если говорить о влиянии, то это они, скорее, испытали влияние славян, нежели его оказали. По мнению автора, об этом свидетельствует их язык, который пронизан славянскими элементами» [Dareste, p. 211].

Если сопоставлять «Записки» Левека и «Исследование истории права» Дареста, становится очевидно, что работа Левека отличается детальным изложением и большей глубиной анализа.

Из современных публикаций о «Русской Правде» следует отметить статью Владимира Водофф (W. Vodoff) [Vodoff], которая представляет собой отчет о лекции Марка Шефтеля (Marc Moise Szeftel), профессора университета Сиэтла (США), о переводе реалий и терминологии средневековых русских судебных кодексов, в том числе и о проблемах пе- 
ревода «Русской Правды». Выделяются следующие филологические проблемы перевода: существование параллельного не анахронического термина; проблема этимологического параллелизма; необходимость пожертвовать точностью термина ради естественности текста перевода [Vodoff, p. 484].

Для иллюстрации были взяты три группы лексики из «Русской Правды»: социальноадминистративные термины, военная лексика и судебная лексика. Наибольшая сложность связана с переводом таких единиц как тиун, закуп и под., которые являются реалиями русского средневекового уклада. Был также рассмотрен перевод лексической единицы вира, и, по мнению автора, русской вире более соответствует единица fredum, а не wergeld, как принято считать. Все три приведенных слова применимы только к убийству человека, однако вира полностью выплачивается князю, a wergeld - семье погибшего, и только часть ее, именуемая fredum, отходит князю. Именно поэтому два данных термина являются эквивалентами древнерусского вира [Vodoff, с. 486]. Как считает Цефтель, основная проблема перевода этого пласта лексики с русского на французский состоит, во-первых, в невозможности подобрать соответствующие эквиваленты во французском языке, поскольку ни один из предложенных вариантов не передает полностью все смыслы, которые заложены в исходном варианте; во-вторых, в противоречии между стремлением к ясности и элегантности стиля, с одной стороны, и точности, с другой.

\section{5}

Таким образом, «Русская Правда» Ярослава Мудрого остается письменным памятником русской истории права, привлекающим внимание как историков, так и филологов-переводчиков.

Предпринятый в статье обзор работ европейских и американских исследователей «Русской Правды», которые сформировали отношение к этому памятнику русского права в западном гуманитарном пространстве и отражают современные тенденции в изучении документа, позволяет констатировать следующее. Историческая и юридическая значи- мость «Русской Правды» признается всеми авторами, и сопоставительный ракурс доминирует в большинстве работ. Сравнение текста как с норманнским «первоисточником», так и с законоуложением других стран эпохи формирования документа приводит авторов рассматриваемых работ к выводу о том, что «Русская Правда» стала ярким свидетельством высокого уровня цивилизационного развития древнерусского общества и сыграла инициальную роль в становлении российской государственности. Перспективным представляется изучение текста документа в парадигме сопоставительного исторического терминоведения, поскольку выявленные в немногих филологических работах сложности перевода терминологических единиц способны сформировать основу для оптимизации интра- и интерязыкового перевода «Русской Правды».

\section{СПИСОК ЛИТЕРАТУРЫ}

Андреев, В. В. Пьер-Шарль Левек о Русской Правде Ярослава Мудрого / В. В. Андреев // Общество. Среда. Развитие. - 2015. - № 1. - С. 77-81.Электрон. текстовые дан. - Режим доступа: http:// www.terrahumana.ru/arhiv/15_01/15_01_13.pdf. Загл. с экрана.

Андреев, В. В. Французские историки о Древней Руси / В. В. Андреев // Русская история. - 2012. № 4. - Электрон. текстовые дан. - Режим доступа: http://rus-istoria.ru/component/k2/item/95frantsuzskie-istoriki-o-drevney-rusi. - Загл. с экрана.

Данилов, А. А. Справочные материалы по истории России IX-XIX веков / А. А. Данилов. М. : Владос, 1998. -432 с.

Зеленов, М. В. Иоганн Филипп Густав Эверс / М. В. Зеленов . - Электрон. текстовые дан. - Режим доступа: http://www.opentextnn.ru/history/ historiografy/historians/ros/?id=473\#_ftn10 - Загл. c экрана.

Орлов, А. С. Август Людвиг Шлецер / А. С. Орлов // Исторический словарь / А. С. Орлов, Н. Г. Георгиева, В. А. Георгиев. - М. : Проспект, 2012. - С. 592.

Толочко, О. П. Краткая редакция Правды Руской: происхождение текста / О. П. Толочко. - К. : Інститут історії України НАН України, 2009. - 136 с.

Усенко, О. Г. О методологии изучения «Русской Правды» / О. Г. Усенко // Вестник Тверского государственного университета. Серия: История. 2007. - № 20. - C. 80-94.

Bieber, U. Ringvorlesung: Kriminelles Mittelalter / U. Bieber // Verbrechen und Diabolik in russischen 
Chronikberichtenhttp (FB Slawistik). - Electronic text data. - Mode of access: www.uni-salzburg.at/fileadmin/ oracle file imports/543254.PDF. - Title from screen.

Dareste, R. Etudes d'histoire du droit / R. Dareste. - Paris : L. Larose et Forcel. LibrairesÉditeurs, 1889. - 418 p. - Electronic text data. - Mode of access: https://play.google.com/booksreader?id $=$ Ti9 Wxli8Ux sC \& printsec $=$ frontcover\&output $=$ reader $\&$ hl $=$ ru\&pg $=$ GBS.PA417. - Title from screen.

Ewers, G. V. Das alteste Recht der Russen in seiner geschichtlichen Entwikelung dargestellt / G. V. Ewers. - Dorpat-Hamburg, 1826. -XVI, 348 S.

Franklin, S. Writing, Society and Culture in Early Rus, ca. 950-1300/S. Franklin. -Cambridge: Cambridge University Press, 2002. - P. 156-157.

Goetz, L. K. Das Russische Recht (Russkaja Pravda). Bd. 1: Die älteste Redaktion des Russischen Rechtes / L. K. Goetz. - Stuttgart : Enke, 1910. - 312 S.

Goetz, L. K. Russkaja pravda „Das Russische Recht" / L. K. Goetz // Aus dem Altrussischen übersetzt, mit Anmerkungen, in: Programm zur Feier des Gedächtnisses des Stifters der Universität Königs Friedrich Wilhelm III., zugleich mit dem Bericht über die akademische Preisverteilung am 3. August 1909.Bonn, 1909. - S. 1-36.

Kaiser, D. H. The Growth of Law in Medieval Russia / D. H. Kaiser. - Princeton : Princeton University Press, 1980. - 324 p. - Electronic text data. - Mode of access: http://faculty.washington.edu/dwaugh/rus/ lexintro.html. - Title from screen.

Kaiser, D. H. The Laws of Rus': Tenth to Fifteenth Centuries / D. H. Kaiser. - Salt Lake City: UT : Charles Schlacks, Jr., 1992. - Electronic text data. - Mode of access: http://faculty.washington.edu/dwaugh/rus/ lexintro.html. - Title from screen.

Lévesque, P.-Ch. Mémoire sur la Pravda Russkaja / P.-Ch. Lévesque ; publié par André Mazon et Michel Laran. - Electronic text data. - Mode of access: http://www.persee.fr/doc/slave 00802557_1962_num_41_1_1789.-Title from screen.

Martin, J. Chapter One. From Kiev to Muscovy. The Beginnings to 1450 / J. Martin // Russia. A History. - Oxford : Oxford University Press, 1997.Electronic text data. - Mode of access: http://www. nytimes.com/books/first/f/freeze-russia.html. - Title from screen.

Riha, Th. Readings in Russian Civilization / Th. Riha // Russia before Peter the Great, 900-1700. Vol. 1. - Chicago : The University of Chicago Press, 1969. - Electronic text data. - Mode of access: http:// bookre.org/reader?file=1200095\&pg=26. - Title from screen.

Schnitzler, J. H. Essai d'une statistique générale de l'Empire de Russie, accompagnée d'aperçus historiques / J. H. Schnitzler. - Paris : F.G. Levrault ; StPétersbourg : J.Brieff, 1829. - 494 p. - Electronic text data. - Mode of access: https://play.google.com/ books/reader?id=Ti9 Wxli 8 Uxs C\&printsec =frontcover\&output=reader\&hl=ru\&pg=GBS.PA417. Title from screen.

Strauch, D. Mittelalterliches nordisches Recht bis 1500: Eine Quellenkunde / D. Strauch // Reallexikon der Germanischen Altertumskunde - Ergänzungsbände. Berlin : Walter de Gruyter, 2011. - Bd. 73. - 886 S.

The Oxford Dictionary of the Middle Ages / ed. by R. E. Bjork. - Oxford : Oxford University Press, 2010. - Electronic text data. - Mode of access: http:// www.oxfordreference.com/search?q=pravda\&search $\mathrm{Btn}=$ Search\&isQuickSearch=true. - Title from screen .

Valk, S. N. Un mémoire de Pierre-Charles Levesque sur Russkaja Pravda / S. N. Valk. - Electronic text data. Mode of access: http://www.persee.fr/doc/slave_00802557_1962_num_41_1_1788. - Title from screen.

Vernadski, G. Medieval Russian Laws / G. Vernadski. - N. Y. : Columbia Univ. Press, 1947. $106 \mathrm{p}$.

Vodoff, W. Histoire et philologie russes / W. Vodoff. - Electronic text data. - Mode of access: https://books.google.frbooks?id=Omt3 KpEgeakC $\& p g=$ PA485\&lpg=PA485\&dq=Le+Mémoire+sur+la + Justice + russe + Ch. + Levesque \& source $=$ bl\&ots $=$ FioRo6Ptb\&sig=oyP0vv18wh6jiHkxxiDr0EWlibM\&hl= fr\&sa $=X \& v e d=0$ ahUKEwiBqOH_jpvKAhULw 3IKHQ8JCKwQ6AEIJjAC\#v=onepage \&q $=\mathrm{Le} \%$ 20M\%C3\%A9moire\%20sur \%201a\%20Justice\%20 russe $\% 20 \mathrm{Ch} . \% 20$ Levesque $\& \mathrm{f}=$ false. - Title from screen.

\section{REFERENCES}

Andreev V.V. Pyer-Sharl Levek o Russkoy Pravde Yaroslava Mudrogo [Pierre-Charles Levesque about the Russkaya Pravda of Yaroslav the Wise]. Obshchestvo. Sreda. Razvitie, 2015, no. 1, pp. 77-81. Available at: http://www.terrahumana.ru/arhiv/15_01/ 15_01_13.pdf.

Andreev V.V. Frantsuzskie istoriki o Drevney Rusi [French Historians on Ancient Russia]. Russkaya istoriya, 2012, no. 4. Available at: http://rus-istoria.ru/ component/k2/item/95-frantsuzskie-istoriki-odrevney-rusi.

Danilov A.A. Spravochnye materialy po istorii Rossii IX-XIX vekov [Reference Materials on the History of Russia of the $9^{\text {th }}-19^{\text {th }}$ Centuries]. Moscow, Vlados Publ., 1998. 432 p.

Zelenov M.V. Iogann Filipp Gustav Evers [Johann Philipp Gustav von Ewers]. Available at: http:// www.opentextnn.ru/history/historiografy/historians/ ros/?id=473\# ftn 10 .

Orlov A.S. Avgust Lyudvig Shletser [August Ludwig (von) Schlözer]. Orlov A.S., Georgieva N.G., 
Georgiev V.A., eds. Istoricheskiy slovar [Historical Dictionary]. Moscow, Prospekt Publ., 2012, p. 592.

Tolochko O.P. Kratkaya redaktsiya Pravdy Ruskoy: proiskhozhdenie teksta [A Brief Version of Russkaya Pravda: Text's Origin]. Kiev, Institut istoriï Ukraïni NAN Ukraïni Publ., 2009. 136 p. (Ruthenica.Supplementum). Available at: http://www. academia.edu/1294251.

Usenko O.G. O metodologii izucheniya «Russkoy Pravdy» [On the Methodology for Studying Russkaya Pravda]. Vestnik Tverskogo gosudarstvennogo universiteta. Seriya: Istoriya, 2007, no. 20, pp. 80-94.

Bieber U. Ringvorlesung: Kriminelles Mittelalter [Course of lectures. The Criminal Middle Ages]. Verbrechen und Diabolik in russischen Chronikberichtenhttp (FB Slawistik) [Diaboliad and crime in the Russian Chronicles]. Available at: www.uni-salzburg.at/fileadmin/oracle_file_imports/ 543254.PDF.

Dareste R. Etudes d'histoire du droit [Study the history of law]. Available at: https://play. google.com/books/reader?id=Ti9Wxli8UxsC\& printsec $=$ frontcover \&output $=$ reader $\&$ hl $=$ ru\&pg $=$ GBS.PA417.

Ewers G.v. Das alteste Recht der Russen in seiner geschichtlichen Entwikelung dargestellt [The ancient law of the Rus in its historical development]. DorpatHamburg, 1826. XVI, 348 p.

Franklin S. Writing, Society and Culture in Early Rus, ca. 950-1300. Cambridge, Cambridge University Press, 2002, pp. 156-157.

Goetz L.K. Das Russische Recht (Russkaja Pravda). Bd. 1: Die älteste Redaktion des Russischen Rechtes [The oldest version of the Russian law]. Stuttgart, Enke, 1910. 312 S. (Sonderabdruck aus: Zeitschrift für vergleichende Rechtswissenschaft, 24)

Goetz L.K. Russkaja pravda „Das Russische Recht" [The Russian Law]. Aus dem Altrussischen übersetzt, mit Anmerkungen, in: Programm zur Feier des Gedächtnisses des Stifters der Universität Königs Friedrich Wilhelm III., zugleich mit dem Bericht über die akademische Preisverteilung am 3. August 1909 [Translated from the old Russian, with notes, in: program for the memory of the founder of the University of king Friedrich Wilhelm III., the report on the academic prize distribution at 3. August, 1909]. Bonn, 1909, pp. 1-36.

Kaiser D.H. The Growth of Law in Medieval Russia. Princeton, Princeton University Press, 1980. 324 p. Available at: http://faculty.washington.edu/ dwaugh/rus/lexintro.html.

Kaiser D.H. The Laws of Rus': Tenth to Fifteenth Centuries. Salt Lake City, UT: Charles Schlacks,
Jr. 1992. Available at: http://faculty.washington.edu/ dwaugh/rus/lexintro.html/.

Levesque P.-Ch. Levesque Pierre-Charles: Mémoire sur la Pravda Russkaja [Levesque P.-Ch. Levesque Pierre-Charles: Memory on the Pravda Russkaja]. Publié par André Mazon et Michel Laran. Available at: http://www.persee.fr/doc/slave_00802557_1962_num_41_1_1789.

Martin J. Chapter One. From Kiev to Muscovy. The Beginnings to 1450. Gregory L. Freeze Russia. A History. Oxford University Press, 1997. Available at: http://www.nytimes.com/books/first/f/freezerussia.html.

Riha Th. Readings in Russian Civilization. Vol. 1. Russia before Peter the Great, 900-1700, ed. $2^{\text {nd }}$ ed. Chicago, The University of Chicago Press, 1969. Available at: http://bookre.org/reader?file=1200095\&pg=26.

Schnitzler J.H. Essai d'une statistique générale de l'Empire de Russie, accompagnée d'aperçus historiques [Overview of General statistics of the Russian Empire with a historical review]. Paris, F.G. Levrault, StPétersbourg, J. Brieff, 1829. - 494 p. Available at: https:// play.google.com/books/reader?id=Ti9Wxli8UxsC $\&$ printsec $=$ frontcover \&output $=$ reader $\&$ hl $=$ ru\&pg $=$ GBS.PA417.

Strauch D. Mittelalterliches nordisches Recht bis 1500: Eine Quellenkunde [Medieval Scandinavian law to 1500: sources]. Reallexikon der Germanischen Altertumskunde - Ergänzungsbände. Bd. 73 [Encyclopedic Handbook of German ancient history]. Berlin, Walter de Gruyter, 2011. 886 S.

The Oxford Dictionary of the Middle Ages. Ed. by Robert E. Bjork. Oxford University Press, 2010. Available at: http://www.oxfordreference.com/ search?q=pravda\&searchBtn=Search\&isQuickSearch $=$ true.

Valk S.N. Un mémoire de Pierre-Charles Levesque sur Russkaja Pravda [Study of PierreCharles Levesque on Russkaja Pravda]. Available at: http://www.persee.fr/doc/slave_0080-2557_1962_ num_41_1_1788.

Vernadski G. Medieval Russian Laws. New York, Columbia Univ. Press, 1947. 106 p.

Vodoff W. Histoire et philologie russes [Russian history and philology]. Available at: https:// books.google.fr/books?id=Omt3 KpEgeakC\&pg= PA485\&lpg=PA485\&dq=Le+Mémoire+sur+la + Justice+ russe + Ch. + Levesque \&source $=$ bl\&ots $=$ FioRo6-Ptb\& sig=oyP0vv18wh6jiHkxxiDr0EWlibM\&hl=fr\&sa= X\&ved=0ahUKEwiBqOH_jpvKAhULw3I KHQ8JCK wQ6AEIJjAC\#v=onepage\&q=Le $\% 20 \mathrm{M} \% \mathrm{C} 3 \%$ A9moire $\% 20$ sur $\% 201$ la $\% 20$ Justice $\% 20$ russe $\% 20$ Ch. $\%$ 20Levesque $\& \mathrm{f}=$ false. 
«Русская Правда»: особенности восприятия в европейском и американском научном пространстве

\section{Information About the Authors}

Vera A. Mityagina, Doctor of Sciences (Philology), Professor, Head of Department of Translation Theory and Practice, Volgograd State University, Prosp. Universitetsky, 100, 400062 Volgograd, Russian Federation, tippvolg@volsu.ru, http://orcid.org/0000-0002-3997-3139.

Svetlana A. Korolkova, Candidate of Sciences (Philology), Associate Professor, Department of Translation Theory and Practice, Volgograd State University, Prosp. Universitetsky, 100, 400062 Volgograd, Russian Federation, tippvolg@volsu.ru, http://orcid.org/0000-0003-2083-4101.

Evgeniya A. Shovgenina, Candidate of Sciences (Philology), Associate Professor, Department of Translation Theory and Practice, Volgograd State University, Prosp. Universitetsky, 100, 400062 Volgograd, Russian Federation, tippvolg@volsu.ru, http://orcid.org/0000-0001-6898-7946.

Aleksandr N. Shovgenin, Candidate of Sciences (Philology), Associate Professor, Department of German and Roman Philology, Volgograd State University, Prosp. Universitetsky, 100, 400062 Volgograd, Russian Federation, shovgenin@volsu.ru, http://orcid.org/0000-0002-5922-8582.

\section{Информация об авторах}

Вера Александровна Митягина, доктор филологических наук, профессор, заведующая кафедрой теории и практики перевода, Волгоградский государственный университет, просп. Университетский, 100, 400062 г. Волгоград, Российская Федерация, tippvolg@volsu.ru, http://orcid.org/ 0000-0002-3997-3139.

Светлана Азадовна Королькова, кандидат филологических наук, доцент кафедры теории и практики перевода, Волгоградский государственный университет, просп. Университетский, 100, 400062 г. Волгоград, Российская Федерация, tippvolg@volsu.ru, http://orcid.org/0000-0003-2083-4101.

Евгения Александровна Шовгенина, кандидат филологических наук, доцент кафедры теории и практики перевода, Волгоградский государственный университет, просп. Университетский, 100, 400062 г. Волгоград, Российская Федерация, tippvolg@volsu.ru, http://orcid.org/0000-00016898-7946.

Александр Николаевич Шовгенин, кандидат филологических наук, доцент кафедры немецкой и романской филологии, Волгоградский государственный университет, просп. Университетский, 100, 400062 г. Волгоград, Российская Федерация, shovgenin@volsu.ru, http://orcid.org/ 0000-0002-5922-8582. 